\title{
Oral Nutrition during and after Critical Illness: SPICES for Quality of Care!
}

\author{
Marjorie Fadeur ${ }^{1,2}$, Jean-Charles Preiser ${ }^{3}{ }^{(1)}$, Anne-Marie Verbrugge ${ }^{2}$, Benoit Misset ${ }^{4}$ and \\ Anne-Françoise Rousseau 2,4,*(D) \\ 1 Department of Diabetes, Nutrition and Metabolic Diseases, University Hospital, University of Liège, \\ Sart-Tilman, 4000 Liège, Belgium; Marjorie.Fadeur@chuliege.be \\ 2 Multidisciplinary Nutrition Team, University Hospital, University of Liège, Sart-Tilman, \\ 4000 Liège, Belgium; am.verbrugge@chuliege.be \\ 3 Erasme University Hospital, Medical Direction, Université Libre de Bruxelles, 1070 Brussels, Belgium; \\ Jean-Charles.Preiser@erasme.ulb.ac.be \\ 4 Department of Intensive Care and Burn Center, University Hospital, University of Liège, Sart-Tilman, \\ 4000 Liège, Belgium; benoit.misset@chuliege.be \\ * Correspondence: afrousseau@chuliege.be; Tel.: +32-4-3667495
}

Received: 14 October 2020; Accepted: 12 November 2020; Published: 14 November 2020

\begin{abstract}
Malnutrition is associated to poor outcomes in critically ill patients. Oral nutrition is the route of feeding in less than half of the patients during the intensive care unit (ICU) stay and in the majority of ICU survivors. There are growing data indicating that insufficient and/or inadequate intakes in macronutrients and micronutrients are prevalent within these populations. The present narrative review focuses on barriers to food intakes and considers the different points that should be addressed in order to optimize oral intakes, both during and after ICU stay. They are gathered in the SPICES concept, which should help ICU teams improve the quality of nutrition care following 5 themes: swallowing disorders screening and management, patient global status overview, involvement of dieticians and nutritionists, clinical evaluation of nutritional intakes and outcomes, and finally, supplementation in macro-or micronutrients.
\end{abstract}

Keywords: critical illness; nutrition rehabilitation; food intake; quality of care; oral nutrition

\section{Introduction}

Insufficient feeding (i.e., intakes lower than losses or expenditure) is frequent in critically ill patients, especially for long stayers in intensive care unit (ICU). Moreover, many patients are admitted with a previous altered nutritional and metabolic status that can be further aggravated by prolonged underfeeding [1]. Thus, critically ill patients should be screened for malnutrition as early as admission, at least using general clinical assessment [2]. In the critical care population, low nutritional intakes are associated with poor outcomes, such as a prolonged ICU or hospital length-of-stay (LOS), a higher incidence of complications (such as infections) and, ultimately, an increased mortality [3-6]. On the contrary, overfeeding can also increase the risk of complications and should thus be avoided [7]. Some authors introduced the concept of "nutritrauma" to raise awareness of the harmful effects of inappropriate nutrition support [8].

Long stayers often experience metabolic, neuroendocrine, and nutritional derangements that are initially triggered by the primary insult and perpetuated by the unresolved failure and persistent inflammation. This situation has been called chronic critical illness (CCI) [9]. These patients carry a high rate of mortality. On another hand, survivors of a critical illness can be affected by the post-intensive care syndrome (PICS), a newly recognized clinical entity characterized by various deficits in physical, 
cognitive, and/or psychological functioning [10]. An underpinning aspect of these two syndromes is muscle wasting and weakness, at least partly due to high muscle protein catabolism [11]; mitochondrial dysfunction and myopathy [12]; prolonged sedation and lack of physical activity [11]; and impaired muscle regeneration [13].

The available literature on nutrition during critical illness raised awareness of the benefits of medical nutrition. Nowadays, nutrition is considered as a major supportive therapy in critically ill patients. Although there is little evidence for the role of increased nutrition delivery in reducing muscle wasting and improving the recovery of critically ill survivors, there is a physiological rationale to consider nutrition in the post-ICU period as equally important as during the ICU stay [14].

\section{Oral Nutrition during and after Critical Illness}

About $40 \%$ of the critically ill patients are able to eat during their ICU stay [15]. Trajectories of orally fed patients in ICU are heterogeneous: oral diet can be exclusive during the entire ICU stay, can be transitioned from a parenteral or enteral nutrition (such as after tracheal extubation), or can be provided simultaneously to enteral nutrition in awake patients.

According to the few studies published so far, critically ill patients who were fed orally had very low intakes in term of both energy and proteins, compared to predicted requirements and recommendations [5,16-20], regardless of the underlying cause. In the different studies, energy intakes varied from 30 to $50 \%$ of the daily requirement or prescription. Protein intakes were even lower and did not reach $40 \%$ of the daily requirement or prescription. To the best of our knowledge, some studies focusing, at least partly, on oral nutrition in critically ill patients are currently active or recruiting worldwide (Table 1). This is encouraging. However, oral nutrition could still be considered as a comfort care, rather than a key component of critical care. When patients look less severely ill, oral nutrition is less closely monitored, and critical-illness-related malnutrition can occur or worsen. The insufficient consideration is reinforced by the fact that we have no idea of the impact on recovery of a mismatch between intakes and needs.

Oral nutrition is not only a question of dose to be ingested. To fuel cells, nutrients have to be absorbed. It has been shown that critically ill patients may exhibit a decreased or delayed gastrointestinal functional absorptive capacity [21,22]. This may limit the beneficial effects of oral nutrition, despite providing adequate quantities.

In the latest update of their recommendations on nutrition practices during critical care, scientific societies highlighted the specific nutritional needs, both quantitatively and qualitatively, of the critically ill patients [2,23]. However, these recommendations are mainly focused on enteral or parenteral nutritional support, during the ICU setting. Due to the paucity of data on oral nutrition during or after an ICU stay, recommendations on oral diet are mostly experts' opinion. This lack of evidence is partly related to the inconsistency of ICU discharge timing and step-down units availability among hospital and research groups, precluding comparisons between different studies.

Currently, there are limited research, and consequently recommendations, on nutrition in the post-ICU period. Oral nutrition provided alone is the most common mode of nutrients provision during this period. During the post-ICU hospital setting, it has been observed in two recent studies that energy and protein intakes were less than estimated or measured requirements $[24,25]$. On the other hand, we are partly blinded on what happens to ICU survivors who are discharged at home without any follow-up in terms of nutritional adequacy and related outcomes. 
Table 1. Planned or ongoing studies including, at least partly, adult critically ill patients or survivors on oral nutrition (sources: ClinicalTrials.gov (https://www.clinicaltrials.gov); EU Clinical Trial Register (https://www.clinicaltrialsregister.eu); Japan Primary Registries Network including JMACCT (http://www.jmacct.med.or.jp/en/ctr/ctr_list_p8.html), UMIN (https://www.umin.ac.jp/ctr/), and JapicCTI (http://www.japic.or.jp/); Australian New Zealand Clinical Trails Registry (https://anzctr.org.au); ISRCTN registry (https://www.isrctn.com)—28 October 2020 and 9 November 2020).

\begin{tabular}{|c|c|c|c|c|c|c|c|c|}
\hline Register Identifier & Design & Region & Inclusion Criteria & Primary Outcome & Secondary Outcomes & Intervention & Comparator & $\begin{array}{c}\text { Planned } \\
\text { Sample Size }\end{array}$ \\
\hline $\begin{array}{c}\text { NCT } \\
04549961\end{array}$ & Observ. & Austria & $\begin{array}{l}\text { Admitted to ICU on } \\
\text { nutritionDay. }\end{array}$ & $\begin{array}{l}60 \text { days hospital mortality. } \\
\text { Length of ICU stay. } \\
\text { Route of nutrition. } \\
\text { Planned and delivered } \\
\text { amount of nutrition in kcal } \\
\text { from all routes. }\end{array}$ & $\begin{array}{l}\text { Number of ICU beds. } \\
\text { Human resources. }\end{array}$ & NA & NA & 3500 \\
\hline $\begin{array}{c}\text { NCT } \\
04274322\end{array}$ & Observ. & China & $\begin{array}{l}\text { Anticipated length of ICU } \\
\text { stay }>48 \mathrm{~h} \text {. } \\
\text { Diagnosed with } 2019 \\
\text { coronavirus disease } \\
\text { (COVID-19). } \\
\text { Food intake difficulties. }\end{array}$ & 28-day all-cause mortality. & $\begin{array}{l}\text { From admission to } 28 \\
\text { days after discharge: } \\
\text { All-cause infection. } \\
\text { Rate of complications. } \\
\text { Length of ICU stay. } \\
\text { Duration of mechanical } \\
\text { ventilation. }\end{array}$ & NA & NA & 117 \\
\hline $\begin{array}{c}\text { NCT } \\
02920086\end{array}$ & $\begin{array}{c}\text { PRT } \\
\text { open label }\end{array}$ & Canada & $\begin{array}{l}\text { 1/ For patients: } \\
>60 \text { years of age OR } 55 \text { years } \\
\text { to } 59 \text { years old with one or } \\
\text { more comorbidities. } \\
\text { Projected duration of ICU } \\
\text { dependency of }>72 \mathrm{~h} \text { from } \\
\text { time of final assessment. } \\
\text { 2/ For family member: } \\
\text { Present and expected to visit } \\
\text { regularly. } \\
\text { The nominated or legally } \\
\text { appointed substitute } \\
\text { decision-maker. } \\
\text { Able to communicate } \\
\text { in English. }\end{array}$ & $\begin{array}{l}\text { Nutritional adequacy during } \\
\text { the ICU stay. } \\
\text { Consumption of ONS. } \\
\text { Caloric intakes on } \\
\text { hospital wards. } \\
\text { Hand grip strength. } \\
\text { Use of shared } \\
\text { decision-making. } \\
\text { Change in decisional conflict. } \\
\text { Family satisfaction with } \\
\text { decision-making. } \\
\text { Overall family satisfaction } \\
\text { with ICU. }\end{array}$ & Not provided. & $\begin{array}{l}\text { 1/Nutrition Education } \\
\text { Program involving } \\
\text { families. } \\
\text { 2/Decision support } \\
\text { program involving } \\
\text { families. }\end{array}$ & Usual care & 150 \\
\hline
\end{tabular}


Table 1. Cont.

\begin{tabular}{|c|c|c|c|c|c|c|c|c|}
\hline Register Identifier & Design & Region & Inclusion Criteria & Primary Outcome & Secondary Outcomes & Intervention & Comparator & $\begin{array}{c}\text { Planned } \\
\text { Sample Size }\end{array}$ \\
\hline ACTRN12620001025921p & Observ. & $\begin{array}{l}\text { Australia and } \\
\text { New Zealand }\end{array}$ & $\begin{array}{l}\text { Adults admitted in ICU for } \\
>48 \mathrm{~h} \text {. }\end{array}$ & $\begin{array}{l}\text { Energy prescription and } \\
\text { intakes. } \\
\text { Feeding intolerances. } \\
\text { Delivery of dietetic services. }\end{array}$ & $\begin{array}{l}\text { Protein prescription } \\
\text { and intakes. } \\
\text { Descriptions in } \\
\text { nutrition practice } \\
\text { variability across } \\
\text { Australia and New } \\
\text { Zealand. } \\
\text { Hospital length-of-stay. } \\
\text { Infectious } \\
\text { complications. }\end{array}$ & NA & NA & 500 \\
\hline ACTRN12620000602921 & Observ. & Australia & $\begin{array}{l}\text { Patients included in Short } \\
\text { Period Incidence Study of } \\
\text { Severe Acute Respiratory } \\
\text { Infection (SPRINT-SARI): } \\
\text { adults with a suspected or } \\
\text { proven acute respiratory } \\
\text { infection requiring new } \\
\text { inpatient admission with } \\
\text { onset within past } 14 \text { days. }\end{array}$ & $\begin{array}{l}\text { Nutrition service delivery. } \\
\text { Nutrition provision. } \\
\text { Proportion of patients } \\
\text { diagnosed with malnutrition } \\
\text { using any of the validated } \\
\text { malnutrition screening and } \\
\text { assessment tools. }\end{array}$ & $\begin{array}{l}\text { Data about nutritional } \\
\text { management during } \\
\text { prone position. }\end{array}$ & NA & NA & 200 \\
\hline UMIN 000040290 & $\begin{array}{l}\text { Interv. } \\
\text { Single arm, } \\
\text { open and not } \\
\text { randomized }\end{array}$ & Japan & $\begin{array}{l}\text { Adults admitted in ICU, } \\
\text { with an expected hospital } \\
\text { stay } \geq 10 \text { days. }\end{array}$ & $\begin{array}{l}\text { Femoral muscle volume } \\
\text { change from day } 1 \\
\text { through } 10\end{array}$ & $\begin{array}{l}\text { MRC score, FSS-ICU, } \\
\text { EQ-5D at ICU } \\
\text { discharge. } \\
\text { Barthel Index at } \\
\text { hospital discharge. } \\
\text { Target nutrition } \\
\text { achievement rate } \\
\text { N-titin level of days 1, 3, } \\
\text { 5, and 7. }\end{array}$ & $\begin{array}{l}\text { Rehabilitation } \\
\text { (including electrical } \\
\text { stimulation of lower } \\
\text { limbs) and nutrition } \\
\text { administration. }\end{array}$ & $\begin{array}{l}\text { Historical } \\
\text { control. }\end{array}$ & 50 \\
\hline UMIN 000042057 & Observ. & Japan & $\begin{array}{l}\text { Adults admitted in ICU for } \\
>3 \text { days. }\end{array}$ & $\begin{array}{l}\text { Protein/non protein calories } \\
\text { ratio, from ICU admission to } \\
\text { the day before hospital } \\
\text { discharge. }\end{array}$ & $\begin{array}{l}\text { Muscle mass and } \\
\text { Barthel Index the day } \\
\text { before hospital } \\
\text { discharge. }\end{array}$ & NA & NA & 180 \\
\hline
\end{tabular}

Abbreviations: NA, not applicable; Observ., observational; Interv., interventional; ONS, oral nutritional supplement; PRT, prospective randomized trial; ICU, intensive care unit. 


\section{Strategies to Optimize Oral Nutrition during and after Critical Illness}

Multiple factors contribute to undernutrition in critically ill patients or survivors. Barriers to consuming adequate nutrition are mainly elated to swallowing disorders, reduced appetite, and food access or food services. Moreover, prescription or delivery of macro- and micronutrients may be inadequate, quantitatively or qualitatively. The "SPICES" concept (Figure 1) is a mnemonic acronym conveying the factors and subsequent strategies that can help reaching adequate food intakes in orally fed patient throughout the entire journey from critical illness to recovery. The concept is composed of the five following themes, described below: swallowing disorders screening and management, patient global status overview, involvement of dieticians and nutritionists, clinical evaluation of nutritional intakes and outcomes, and finally, supplementation in macro- or micronutrients.

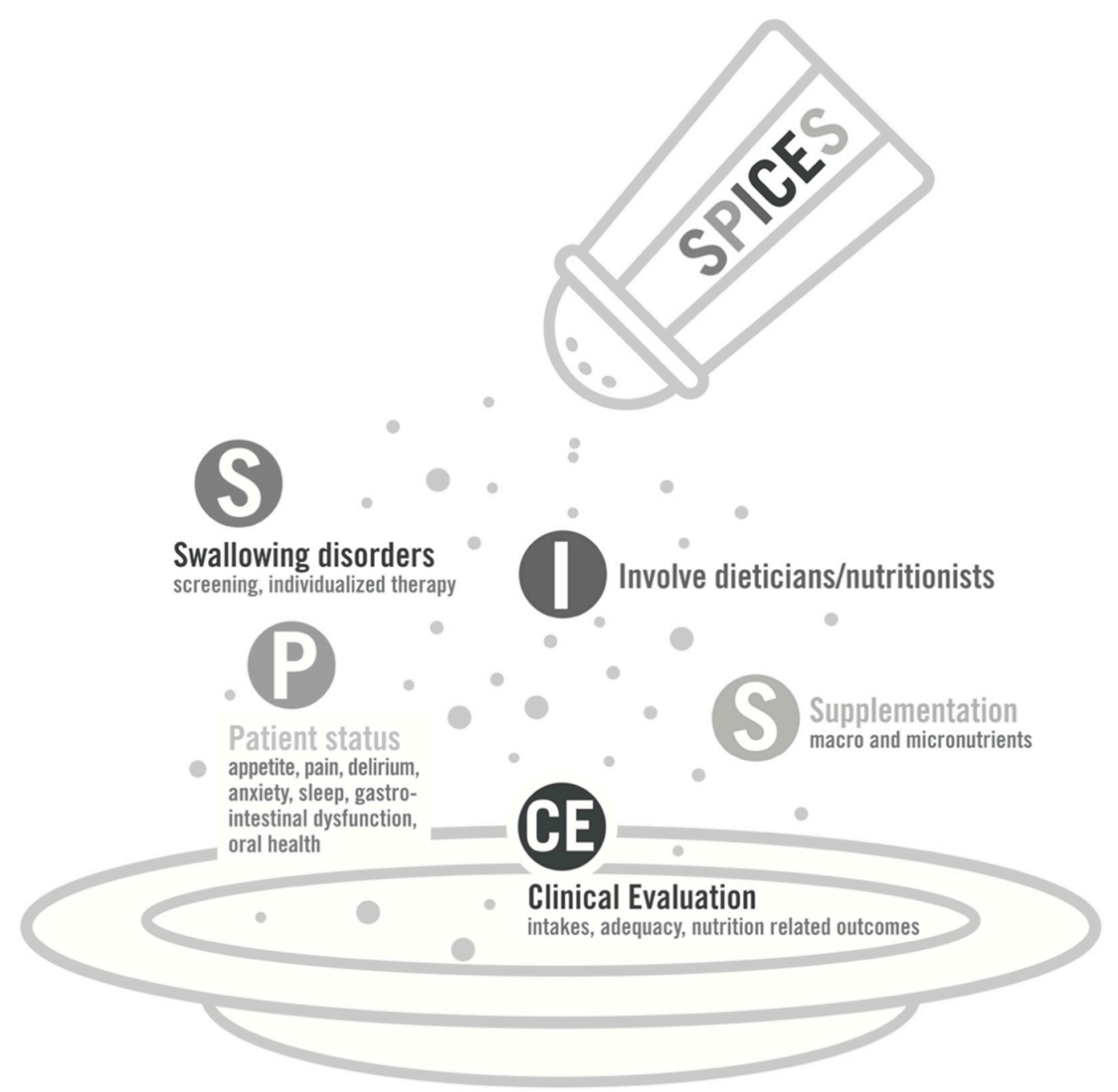

Figure 1. SPICES concept, detailing the different points to be addressed in a critically ill patient or an intensive care unit (ICU) survivor, aiming to optimize oral feeding.

\section{S: Swallowing disorders screening and management}

Swallowing dysfunction is induced by damage to the central nervous system, tracheal intubation, and presence of a nasogastric tube or a tracheostomy [26]. The duration of mechanical ventilation seems to be a prominent risk factor [27]. Reported incidences are highly variable, depending on the patient selection, the timing, and the method of assessment. The frequency of long-term mild-to-severe dysphagia in ICU survivors of severe sepsis reaches the range of stroke survivors [28]. However, this important concern still suffers from limited awareness and screening [29]. Typical clinical signs 
evoking dysphagia are listed in Table 2. Further assessment of dysphagia is based on screening questionnaires, clinical observation, and bedside non-instrumental evaluation. A number of tools are available: they generally involve the swallowing of a volume, defined in terms of quantity and viscosity. Even if they were initially proposed for non-ICU patients, some of the tools, such as the volume-viscosity swallow test (V-VST), are safely suitable in the acute care setting [30]. Final diagnosis is obtained using instrumental tests, such as oropharyngo-esophageal scintigraphy or flexible endoscopic evaluation $[26,29]$. The latter is considered as the gold standard technique, but its use should be strictly limited in patients with coronavirus disease 2019 (COVID-19) [31].

Table 2. Clinical signs of dysphagia.

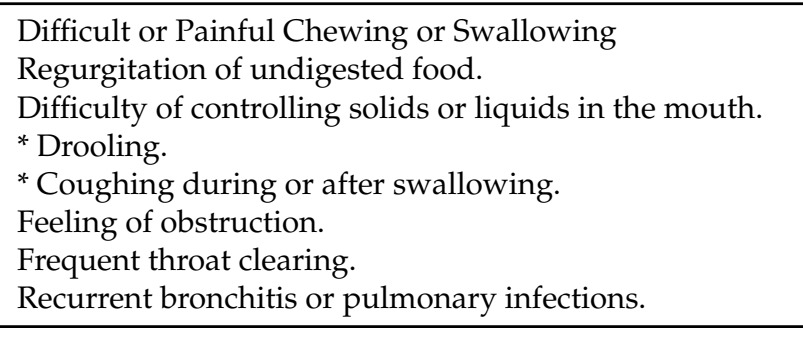

${ }^{*}$ recurrent items in non-instrumental assessment tools.

Dietary texture modification is a major therapeutic pillar for dysphagia. The food textures (and drink thickness) are described using the International Dysphagia Diet Standardization Initiative (IDDSI) Framework terminology [32,33]. The type of texture is prescribed according to the results of the swallowing assessment. However, these modifications can lead to patient dissatisfaction and reduced intakes. The variety of food that can be modified is quite limited, and meals are then uniform. Moreover, switching food to (semi-)liquid textures lowers the nutrients density. Texture modification should be associated to active deglutition rehabilitation, guided by speech-language therapist, and including postural changes, compensatory maneuvers (i.e., special swallowing techniques), and therapeutic exercises. Pharyngeal electrical stimulation is an invasive treatment approach, at present mostly used in stroke-related dysphagia [29].

\section{P: Patient global status overview}

Many factors related to patient status can interfere with oral nutrition. Not all can be changed, managed, or treated. At best, they should all be considered in order to adjust the nutritional strategy.

Appetite is commonly reduced, from early during critical illness, to at least 3 months after discharge [34,35]. A relationship between nutritional intakes and levels of gut released peptides has been described. In critically ill patients, peptide YY, a hormone that inhibits appetite, has been shown to be high, while ghrelin, a peptide that stimulates appetite, was low [36]. Beside appetite changes, taste can be altered by medications or viral infections, such as COVID-19; satiety can be modified; and gastric emptying can be impaired. Moreover, patients can further suffer from nausea, pain, anxiety, delirium, or sleep disturbances. Muscle weakness and reduced physical capacity have secondary effects on chewing fatigue and ability to self-feed. Finally, food intake is driven by individual, social, or environmental determinants.

Eating preferences and habits or religious food restrictions can reduce the list of palatable foods or the qualitative composition of meals. Social isolation and absence of commensality are well-known factors contributing to poor eating behaviors, as predominantly demonstrated in the elderly population [37]. Such conditions are easily reproduced in ICU, especially in units without open visitation policy, where patients eat alone. The eating environment (light, noise, odor, seating comfort) impacts food consumption [38] but is not always adequate in hospitals. Unfortunately, impact of all these factors on nutritional intakes in critically ill patients have not been widely studied. 


\section{I: Involvement of dieticians and nutritionists}

In hospital, another category of barriers to food intake are organizational factors [39]. Food delivery can be inappropriate in terms of timing in patients who suffer from sleep disturbances. Portion size may be inadequate in view of reduced appetite. Basic appearance, inappropriate temperature, microwave heating, or bland taste can make the dishes unappetizing. Moreover, some meals can be missed due to mandatory fasting for invasive procedures or surgeries. Traditionally, access to food is limited between meals, and ordering systems are poorly flexible [40].

Dieticians/nutritionists have a key role in optimizing oral nutrition during ICU and hospital stay [19]. They assist critical care and hospital teams by improving the feeding process in terms of food access and delivery. They also help to formulate the oral nutritional intervention, aiming to individualize the nutritional support. A clear nutritional plan should be established, based on the patient's food desires and nutritional requirements. This plan should thus be further communicated to ward teams, to general practitioners, and finally, to patients and families, who may lack specialized knowledge about the complex requirements of a recovering ICU survivor. A closed follow-up by the dietetic team may help ICU survivors to reach adequate nutritional intakes during their recovery.

\section{CE: Clinical Evaluation of nutritional intakes and outcomes}

Metabolic response and, subsequently, nutritional strategies vary according to the critical illness trajectory. Even if still vague from a clinical point of view, three phases may be described [2,41]: after injury or insult, the acute phase is composed of an early and a late period, before progressing to late phase (Figure 2). Macronutrient intakes during the acute phase are progressively increased to reach at least 70\% of energy expenditure (EE) (or 20-25 kcal/kg/day) and maximum $1.3 \mathrm{~g} / \mathrm{kg} / \mathrm{day}$ proteins between day 3 to day 7 at the latest [2,42]. These European recommendations are valid for either medical nutrition or oral nutrition. During the late phase, corresponding to either CCI and/or convalescence and rehabilitation, higher protein intakes and energy targets may be assumed. As an example, some authors [43] suggest, during the post-ICU phase at hospital, to increase energy intakes to $125 \%$ of the predicted requirements or to daily provide $30 \mathrm{kcal} / \mathrm{kg}$ and to increase protein intakes to $1.5-2 \mathrm{~g} / \mathrm{kg} /$ day. After post-hospital discharge, energy intakes could be increased to $150 \%$ of the predicted requirements or to provide $35 \mathrm{kcal} / \mathrm{kg}$ energy per day. During that recovery period, protein intakes could even be higher than $2 \mathrm{~g} / \mathrm{kg} /$ day. These targets make sense based on the available literature but still need to be validated in post-ICU studies.

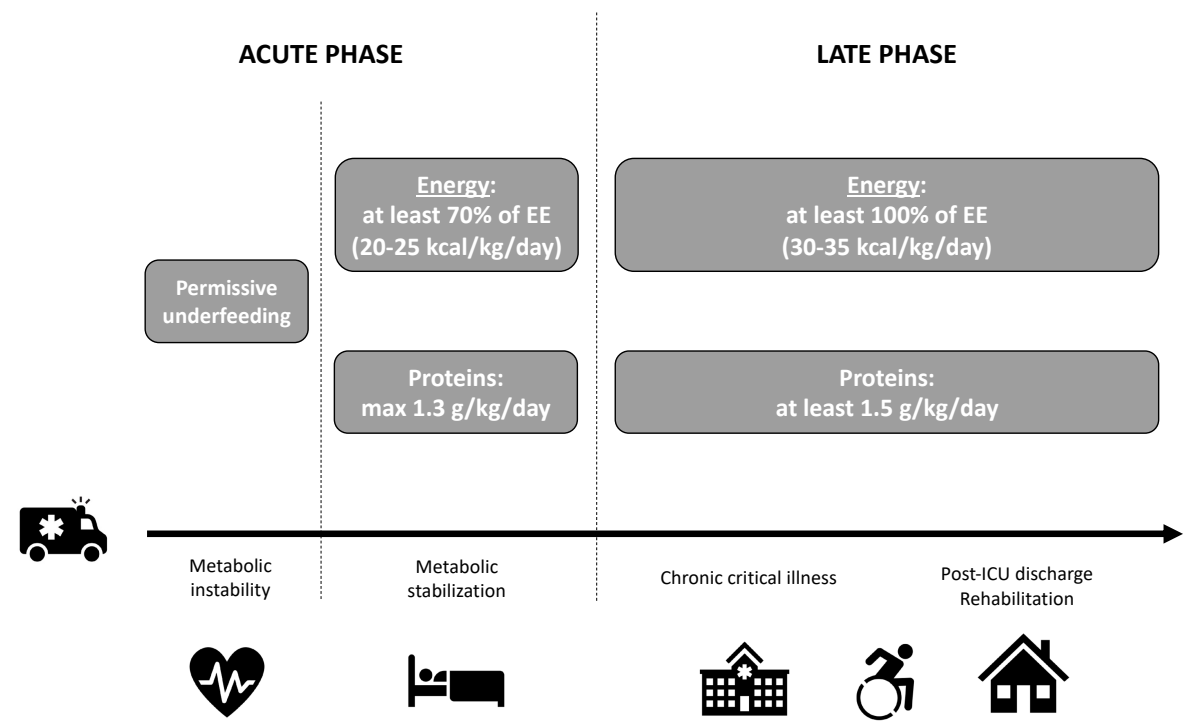

Figure 2. Calories and proteins provision by oral route, according to the successive phases of the critical care pathway (adapted from $[23,39,41]$ ). Abbreviations: EE, energy expenditure; max, maximum. 
At best, energy targets should be determined using repeated indirect calorimetry [2] that measures inspired and expired gas exchanges to calculate EE. Even if its benefits on outcomes are not established [44], critically ill patients are good candidates for indirect calorimetry [45]. It is now recognized that predictive equations are not accurate enough and that metabolic status of critically ill patients or survivors are highly dynamic during their ICU path, with high inter-individual variability [45]. New generation of calorimeter allow easily and accurate measurement of EE in spontaneously breathing patients [46,47]. Unfortunately, indirect calorimetry using canopy is not always feasible (i.e., in case of oxygen supply) or widely available. Simpler appreciations are derived from predictive equations. It is noteworthy that these predictive equations are associated with significant inaccuracy, leading to inadequate evaluation of the energy needs [48]. The least inexact equation is the Penn State equation for ICU patients [49]. The simplest estimation of energy requirements are weight-based equations, as described in Figure 2.

Nutritional interventions should be monitored, especially as needs are very dynamic throughout the critical illness journey. First, it is important to monitor what the patient really receives and eats and assure that nutrition is provided as planned and prescribed. Yet, as stated above, nutrition delivery or intakes are often inferior to prescription. Daily and cumulated energy and protein balances should be calculated (net balance $=$ target - delivery). In hospital, this can be performed advantageously using computerized management systems [50,51]. Through such tools, the nutrition delivery has been shown to be closer to the targets [52]. For survivors' follow-up, telemedicine is another option: text messaging or smart-phone applications have become widely used interfaces between patients and providers. Mobile-based dietary assessment tools are emerging and promising, but the accuracy of their database still needs to be improved [53]. Secondly, nutrition interventions should be evaluated for effectiveness. How the patient responds to the delivered nutrients is another key assessment. Nutrition-related outcomes include biomarkers. Serum albumin and prealbumin are traditional biomarkers thought to reflect nutritional status. However, due to their relationship with systemic inflammation response, they are not sensitive markers of energy and protein intake adequacy [54]. It might be useful to observe the evolution of body composition, muscle architecture, muscle strength, and physical function from ICU to full recovery [55]. The frequency of repetitions has not been determined.

\section{$S$ : Supplementation in macro- and/or micronutrients}

Nutritional targets may be found enormous by patients, compared to the amounts they are able to ingest. In order to achieve macronutrients targets in ICU patients who receive oral nutrition and in ICU survivors, food enrichment or oral nutrition supplements (ONS) will often need to be considered $[24,43,56]$. This is particularly the case for patients with dysphagia who need liquidized (IDDSI 3), pureed (IDDSI 4), or minced and moist (IDDSI 5) foods. Food such as cream, yogurt, fruit purée, mashed potatoes, milk, coffee, or soup can be enriched by adding maltodextrin or protein powders. These powders are neutral in taste. Maltodextrin powder contains around $380 \mathrm{kcal} / 100 \mathrm{~g}$. Protein powder contains around $90 \mathrm{~g}$ protein/100 g. ONS can be either liquid (drinks) or, less frequently, semi-solid (creams). Drinkable ONS are milk or fruit juice derived. A number of commercial products are available, varying in term of flavor, fiber composition, and volume. They contain macronutrients and micronutrients at varying levels of concentrations. Calories generally range from 150 to $400 \mathrm{kcal} /$ portion, and protein concentration ranges from 8 to $20 \mathrm{~g} /$ portion. Generally, ONS are prescribed one or twice daily, respecting patient's flavor choices. Information regarding ONS intake should be provided to patients: they should be advised to take ONS between meals, aiming to avoid spoiling appetite.

Especially during ICU or hospital stay, patients are not able to ingest sufficient enriched food or ONS to reach the macronutrients targets. In these patients, a supplemental enteral feeding should be considered. In particular, after extubation when there is a high incidence of swallowing disorders and weakness, the naso-gastric tube should probably not be hastily removed, at least until oral intakes ensure adequate energy and protein provision.

Deficits in micronutrients are suspected to be frequent in ICU survivors, as a result of severe illness itself, drug interactions, increased consumption, or extensive losses of biologic fluids. Iatrogenic 
losses may be related to sedation administration [57] or to insufficient repletion during continuous renal replacement therapy (CRRT) [58]. Magnitude of such deficits is not well-documented in the current literature [59]. Moreover, micronutrient status is difficult to approach: routine lab assessment is not common and is expensive, and the plasma concentrations are influenced by systemic inflammatory response $[60,61]$. In the latter case, concentrations should be interpreted with caution as low values do not necessarily reflect deficiency, and normal values do not necessarily indicate satisfactory bioavailability or bioefficiency.

Micronutrients are vital as intermediaries in metabolism and have potential roles in wound healing, cellular immunity, and oxidative stress. If possible, they should come from a well-balanced diet. However, micronutrient requirements may not be covered by oral diet alone, due to suboptimal eating patterns or temporary increased requirements [62]. Unlike burn patients for whom some recommendations are published [63], appropriate dose, route, and length of supplementation are unknown or controversial in critical ill patients. At least, the provision of dietary references should be guaranteed [64]. Especially in trauma patients, in burn patients, or in the case of wound healing disorders, tailored nutritional measures or supplementation in micronutrients could be beneficial [65] (Table 3). Supplementation or repletion in some micronutrients can be administered orally, separately, or as commercial preparations of multivitamins and minerals. Unfortunately, the oral route can be associated with reduced bioavailability or competition between trace elements (such as zinc and copper). Other at-risk populations are known to have altered micronutrient status, such as patients with severe acute kidney injury (regardless of treatment with CRRT) [66], alcoholic patients, patients on proton pump inhibitors or metformin, and patients who benefited from a bariatric surgery (Table 3) [62,67-69]. In these situations, the effect of micronutrients supplementation still needs to be explored.

Table 3. Frequent clinical situations at risk of micronutrient deficiency and the corresponding suggested supplementation during ICU stay or in ICU survivors (adapted from [62,69]).

\begin{tabular}{cc}
\hline Clinical Situation & Micronutrient Supplementation \\
\hline $\begin{array}{c}\text { Suboptimal eating patterns. } \\
\text { Energy intake }<1500 \mathrm{kcal} / \text { day. }\end{array}$ & $\begin{array}{c}\text { Multivitamins/multiminerals, vitamin D, calcium, } \\
\text { vitamin B12, magnesium. }\end{array}$ \\
\hline Prolonged ICU and/or hospital stay. & Vitamin D, calcium. \\
\hline Prolonged wound healing, polytrauma. & Multivitamins/multiminerals. \\
\hline PPI (long term treatment). & Vitamin B12, magnesium, calcium. \\
\hline Severe acute kidney injury, CRRT. & Multivitamins/multiminerals. \\
\hline Persistent kidney disease. & Vitamin D, vitamin K. \\
\hline Post-bariatric surgery status. & Multivitamins/multiminerals, vitamin D, calcium, \\
vitamin B12, iron.
\end{tabular}

Abbreviations: CRRT, continuous renal replacement therapy; ICU, intensive care unit; PPI, proton pump inhibitor.

Notwithstanding, the lack of dedicated recommendations, there are some rationales for some micronutrients to be continued after ICU or hospital discharge. According to recent data, iron deficiency, diagnosed using hepcidin, is very frequent at ICU discharge and has been associated to poor one-year physical recovery [70]. Indeed, iron deficiency causes fatigue and muscle weakness, independently of anemia [71]. Magnesium and selenium correlate to muscle mass and muscle performances [72].

Vitamin D insufficiency or deficiency is very common in critically ill patients and has been associated with adverse outcomes [73]. Many of these patients enter the ICU with a pre-existing deficient status. However, hypovitaminosis D can be induced by the ICU stay and the critical illness themselves. The cause is multifactorial: lack of exposure to sunlight, inadequate intakes, malabsorption, and altered metabolism [74]. Among the pleiotropic effects of vitamin D, its beneficial effect on immunity or muscles is undebated $[75,76]$. A normal vitamin $\mathrm{D}$ level requires regular vitamin 
D supplementation in many individuals, typically in a daily dose of 600 to 2000 IU [77]. There is now evidence that higher replacement dosage may be required in critically ill patients, compared to other populations [78]. The benefit of supplementation may vary according to the vitamin $\mathrm{D}$ status. In the VITdAL-ICU study, high doses of cholecalciferol reduced 28-day mortality only in patients with very low levels of 25(OH)-D [79]. Moreover, preliminary reports suggest a beneficial effect of vitamin D3 supplementation in increasing quadriceps strength in adults with vitamin D deficiency [80], as well as in the post-burn period $[81,82]$.

\section{Perspectives in Nutrition Therapy and Metabolic Support}

Adjuvant therapies to nutritional support are increasingly discussed, aiming to optimize nutritional support or modulate metabolic status in ICU patients or survivors. Orally fed patients during ICU stay or after discharge could theoretically benefit from such strategies. However, only a few data are available up to now to guide their prescription, particularly the optimal timing of introduction. Depending on future evidence, metabolic support could become one of the features of "supplementation", as an upgrade of the last "S" of the SPICES concept.

Carnitine is an amino acid derivate, which places a crucial role in fatty acid transport and $\beta$-oxidation, and at least, in mitochondrial energetic functioning [83]. Carnitine deficiency should be suspected in chronic critically ill patients and in patients who were dependent on CRRT or parenteral nutrition. Relevant signs include unexplained hypertriglyceridemia, fatty liver, or myopathy [54]. Carnitine can be measured in plasma: low level is an additional argument for supplementation, at least orally (0.5-1 g/day) [84].

Ghrelin agonists are a therapeutic perspective to help overcome the reduced appetite experienced by critically ill patients and survivors. According to preliminary studies in animals or some groups of patients, benefits could be multiple: improvement of food intake, but also the additional effect on the upregulation of the growth hormone axis, or the modulation of the inflammatory response [85]. Unfortunately, in a recent study in critically patients (although enterally fed), the ghrelin agonist ulimorelin failed to be superior to metoclopramide in term of gastric emptying [86]. More data are needed before ghrelin modulation could be implemented in clinical practice.

Nutrition rehabilitation should probably be viewed as a part of a multimodal strategy aiming to enhance recovery. Conceptually, such a strategy should at least combine adequate nutrition and active physical exercises [87]. Evidence is still weak $[88,89]$. In a recent study that should be interpreted with caution due to protein target in the control group, authors observed that a high protein regimen provided better muscle mass maintenance only with associated active rehabilitation [90]. Anabolic agents, anticatabolic agents, and specific nutrients could be additional and innovative approaches, aiming to modulate muscle wasting [87]. It is thought that the five approaches could be synergistic. However, in the absence of strong evidence in critically ill patients, such a combination is not yet systematically recommended. Probably, it should rather be prescribed on an individualized basis.

The rationales for prescribing anabolic agents, and particularly testosterone and analogues, are the sustained catabolism and the anabolic resistance observed in ICU survivors [13,91]. This ongoing metabolic status is associated with testosterone deficiency [92], further increased by opioid use [93]. Anabolic agents have been more widely studied in severe burn patients: oxandrolone, an androgen analogue, safely induces a gain in lean body mass during the rehabilitative phase [94]. Administration of recombinant human growth hormone (rhGH) is not recommended in critically ill adults. Unlike in the general intensive care population [95], no adverse impact on mortality was observed in burn patients. However, in burn adults, rhGH effects were not better than oxandrolone [96], while disclosing adverse hyperglycemia. At present, patients who will benefit the most from anabolic treatments are not clearly identified, as well as the optimal timing of administration or even dosage.

The majority of the published data about benefits of anticatabolic agents arises again from the severe burn population. Treatment with non-selective beta-blockers (i.e., propranolol) reverses muscle protein catabolism in severe burn children [97] and does not impede exercise-induced increases in 
muscle strength [98]. In an old study including head-injured patients, propranolol also reduced the observed resting hypermetabolism [99]. Unfortunately, since those princeps studies, there has been no significant advances with this treatment in non-burn critically ill patients.

The amino acid leucine is known to promote muscle protein synthesis [100]. $\beta$-Hydroxy- $\beta$ methylbutyrate (HMB), a metabolite of leucine, improves muscle mass and muscle strength in a variety of clinical groups [101]. Type (leucine or HMB) and dose of amino-acid supplementation is still unknown, as well as the best phase of critical illness in which to provide this.

\section{Conclusions}

Malnutrition is a significant concern for the critically ill patients who are fed orally. ICU survivors remain vulnerable, at least for months following discharge. In the absence of dedicated recommendations about macro- and micronutrients, careful nutritional management of oral nutrition during and after an ICU stay should appeal to common sense. Any problem limiting food intakes should be addressed. A closed monitoring of daily intakes, their adequacy with nutritional requirements, and nutritional-related outcomes should be set up early and prolonged after discharge. Intervention of a multidisciplinary team including a dietician is crucial, helping to raise awareness among ICU caregivers about difficulties in feeding critically ill patients orally. There is an urgent need for studies clarifying the condition of orally fed patients during and after ICU stay.

Author Contributions: Writing—original draft preparation, M.F. and A.-F.R.; writing—review and editing, J.-C.P., A.-M.V., and B.M.; supervision, A.-F.R. All authors have read and agreed to the published version of the manuscript.

Funding: This research received no external funding.

Acknowledgments: We would like to thank Louis Maraite and Béatrice Duculot for their valuable help for the illustration of this manuscript.

Conflicts of Interest: All authors declare that they have no competing interest.

\section{References}

1. Viana, M.V.; Pantet, O.; Bagnoud, G.; Martinez, A.; Favre, E.; Charriere, M.; Favre, D.; Eckert, P.; Berger, M.M. Metabolic and Nutritional Characteristics of Long-Stay Critically Ill Patients. J. Clin. Med. 2019, 8, 985. [CrossRef] [PubMed]

2. Singer, P.; Blaser, A.R.; Berger, M.M.; Alhazzani, W.; Calder, P.C.; Casaer, M.P.; Hiesmayr, M.; Mayer, K.; Montejo, J.C.; Pichard, C.; et al. ESPEN guideline on clinical nutrition in the intensive care unit. Clin. Nutr. 2019, 38, 48-79. [CrossRef] [PubMed]

3. Casaer, M.P.; Van den Berghe, G. Nutrition in the acute phase of critical illness. N. Engl. J. Med. 2014, 370, 1227-1236. [CrossRef] [PubMed]

4. Dvir, D.; Cohen, J.; Singer, P. Computerized energy balance and complications in critically ill patients: An observational study. Clin. Nutr. 2006, 25, 37-44. [CrossRef]

5. Villet, S.; Chiolero, R.L.; Bollmann, M.D.; Revelly, J.P.; Cayeux, R.N.M.; Delarue, J.; Berger, M.M. Negative impact of hypocaloric feeding and energy balance on clinical outcome in ICU patients. Clin. Nutr. 2005, 24, 502-509. [CrossRef]

6. Lew, C.C.H.; Yandell, R.; Fraser, R.J.L.; Chua, A.P.; Chong, M.F.F.; Miller, M. Association between Malnutrition and Clinical Outcomes in the Intensive Care Unit: A Systematic Review. JPEN J. Parenter. Enter. Nutr. 2017, 41, 744-758. [CrossRef]

7. Klein, C.J.; Stanek, G.S.; Wiles, C.E., 3rd. Overfeeding macronutrients to critically ill adults: Metabolic complications. J. Am. Diet. Assoc. 1998, 98, 795-806. [CrossRef]

8. Yebenes, J.C.; Campins, L.; Martinez de Lagran, I.; Bordeje, L.; Lorencio, C.; Grau, T.; Montejo, J.C.; Bodi, M.; Serra-Prat, M.; Working Group on Nutrition and Metabolism of the Spanish Society of Critical Care. Nutritrauma: A Key Concept for Minimising the Harmful Effects of the Administration of Medical Nutrition Therapy. Nutrients 2019, 11, 1775. [CrossRef]

9. Schulman, R.C.; Mechanick, J.I. Metabolic and nutrition support in the chronic critical illness syndrome. Respir. Care 2012, 57, 958-978. [CrossRef] 
10. Needham, D.M.; Davidson, J.; Cohen, H.; Hopkins, R.O.; Weinert, C.; Wunsch, H.; Zawistowski, C.; Bemis-Dougherty, A.; Berney, S.C.; Bienvenu, O.J.; et al. Improving long-term outcomes after discharge from intensive care unit: Report from a stakeholders' conference. Crit. Care Med. 2012, 40, 502-509. [CrossRef]

11. Batt, J.; Herridge, M.; Dos Santos, C. Mechanism of ICU-acquired weakness: Skeletal muscle loss in critical illness. Intensive Care Med. 2017, 43, 1844-1846. [CrossRef] [PubMed]

12. Kress, J.P.; Hall, J.B. ICU-acquired weakness and recovery from critical illness. N. Engl. J. Med. 2014, 370, 1626-1635. [CrossRef] [PubMed]

13. Dos Santos, C.; Hussain, S.N.; Mathur, S.; Picard, M.; Herridge, M.; Correa, J.; Bain, A.; Guo, Y.; Advani, A.; Advani, S.L.; et al. Mechanisms of Chronic Muscle Wasting and Dysfunction after an Intensive Care Unit Stay. A Pilot Study. Am. J. Respir. Crit. Care Med. 2016, 194, 821-830. [CrossRef] [PubMed]

14. Bear, D.E.; Wandrag, L.; Merriweather, J.L.; Connolly, B.; Hart, N.; Grocott, M.P.W.; Enhanced Recovery After Critical Illness Programme Group investigators. The role of nutritional support in the physical and functional recovery of critically ill patients: A narrative review. Crit. Care 2017, 21, 226. [CrossRef] [PubMed]

15. Bendavid, I.; Singer, P.; Theilla, M.; Themessl-Huber, M.; Sulz, I.; Mouhieddine, M.; Schuh, C.; Mora, B.; Hiesmayr, M. NutritionDay ICU: A 7 year worldwide prevalence study of nutrition practice in intensive care. Clin. Nutr. 2017, 36, 1122-1129. [CrossRef] [PubMed]

16. Berger, M.M.; Chiolero, R.L.; Pannatier, A.; Cayeux, M.C.; Tappy, L. A 10-year survey of nutritional support in a surgical ICU: 1986-1995. Nutrition 1997, 13, 870-877. [CrossRef]

17. Peterson, S.J.; Tsai, A.A.; Scala, C.M.; Sowa, D.C.; Sheean, P.M.; Braunschweig, C.L. Adequacy of oral intake in critically ill patients 1 week after extubation. J. Am. Diet. Assoc. 2010, 110, 427-433. [CrossRef]

18. Rougier, L.; Preiser, J.C.; Fadeur, M.; Verbrugge, A.M.; Paquot, N.; Ledoux, D.; Misset, B.; Rousseau, A.F. Nutrition During Critical Care: An Audit on Actual Energy and Protein Intakes. JPEN J. Parenter. Enter. Nutr. 2020. [CrossRef]

19. Soguel, L.; Revelly, J.P.; Schaller, M.D.; Longchamp, C.; Berger, M.M. Energy deficit and length of hospital stay can be reduced by a two-step quality improvement of nutrition therapy: The intensive care unit dietitian can make the difference. Crit. Care Med. 2012, 40, 412-419. [CrossRef]

20. Moisey, L.L.; Pikul, J.; Keller, H.; Yeung, C.Y.E.; Rahman, A.; Heyland, D.K.; Mourtzakis, M. Adequacy of Protein and Energy Intake in Critically Ill Adults Following Liberation From Mechanical Ventilation Is Dependent on Route of Nutrition Delivery. Nutr. Clin. Pract. 2020. [CrossRef]

21. Johnston, J.D.; Harvey, C.J.; Menzies, I.S.; Treacher, D.F. Gastrointestinal permeability and absorptive capacity in sepsis. Crit. Care Med. 1996, 24, 1144-1149. [CrossRef] [PubMed]

22. Deane, A.M.; Summers, M.J.; Zaknic, A.V.; Chapman, M.J.; Di Bartolomeo, A.E.; Bellon, M.; Maddox, A.; Russo, A.; Horowitz, M.; Fraser, R.J. Glucose absorption and small intestinal transit in critical illness. Crit. Care Med. 2011, 39, 1282-1288. [CrossRef] [PubMed]

23. McClave, S.A.; Taylor, B.E.; Martindale, R.G.; Warren, M.M.; Johnson, D.R.; Braunschweig, C.; McCarthy, M.S.; Davanos, E.; Rice, T.W.; Cresci, G.A.; et al. Guidelines for the Provision and Assessment of Nutrition Support Therapy in the Adult Critically Ill Patient: Society of Critical Care Medicine (SCCM) and American Society for Parenteral and Enteral Nutrition (A.S.P.E.N.). JPEN J. Parenter. Enter. Nutr. 2016, 40, 159-211. [CrossRef] [PubMed]

24. Ridley, E.J.; Parke, R.L.; Davies, A.R.; Bailey, M.; Hodgson, C.; Deane, A.M.; McGuinness, S.; Cooper, D.J. What Happens to Nutrition Intake in the Post-Intensive Care Unit Hospitalization Period? An Observational Cohort Study in Critically Ill Adults. JPEN J. Parenter. Enter. Nutr. 2019, 43, 88-95. [CrossRef] [PubMed]

25. Chapple, L.S.; Deane, A.M.; Heyland, D.K.; Lange, K.; Kranz, A.J.; Williams, L.T.; Chapman, M.J. Energy and protein deficits throughout hospitalization in patients admitted with a traumatic brain injury. Clin. Nutr. 2016, 35, 1315-1322. [CrossRef]

26. Macht, M.; White, S.D.; Moss, M. Swallowing dysfunction after critical illness. Chest 2014, 146, 1681-1689. [CrossRef]

27. Zuercher, P.; Schenk, N.V.; Moret, C.; Berger, D.; Abegglen, R.; Schefold, J.C. Risk Factors for Dysphagia in ICU Patients after Invasive Mechanical Ventilation. Chest 2020, 158, 1983-1991. [CrossRef]

28. Zielske, J.; Bohne, S.; Brunkhorst, F.M.; Axer, H.; Guntinas-Lichius, O. Acute and long-term dysphagia in critically ill patients with severe sepsis: Results of a prospective controlled observational study. Eur. Arch. Otorhinolaryngol. 2014, 271, 3085-3093. [CrossRef] 
29. Zuercher, P.; Moret, C.S.; Dziewas, R.; Schefold, J.C. Dysphagia in the intensive care unit: Epidemiology, mechanisms, and clinical management. Crit. Care 2019, 23, 103. [CrossRef]

30. Clave, P.; Arreola, V.; Romea, M.; Medina, L.; Palomera, E.; Serra-Prat, M. Accuracy of the volume-viscosity swallow test for clinical screening of oropharyngeal dysphagia and aspiration. Clin. Nutr. 2008, 27, 806-815. [CrossRef]

31. Frajkova, Z.; Tedla, M.; Tedlova, E.; Suchankova, M.; Geneid, A. Postintubation Dysphagia During COVID-19 Outbreak-Contemporary Review. Dysphagia 2020, 35, 549-557. [CrossRef] [PubMed]

32. Steele, C.M.; Namasivayam-MacDonald, A.M.; Guida, B.T.; Cichero, J.A.; Duivestein, J.; Hanson, B.; Lam, P.; Riquelme, L.F. Creation and Initial Validation of the International Dysphagia Diet Standardisation Initiative Functional Diet Scale. Arch. Phys. Med. Rehabil. 2018, 99, 934-944. [CrossRef] [PubMed]

33. Cichero, J.A.; Lam, P.; Steele, C.M.; Hanson, B.; Chen, J.; Dantas, R.O.; Duivestein, J.; Kayashita, J.; Lecko, C.; Murray, J.; et al. Development of International Terminology and Definitions for Texture-Modified Foods and Thickened Fluids Used in Dysphagia Management: The IDDSI Framework. Dysphagia 2017, 32, 293-314. [CrossRef] [PubMed]

34. Chapple, L.S.; Weinel, L.M.; Abdelhamid, Y.A.; Summers, M.J.; Nguyen, T.; Kar, P.; Lange, K.; Chapman, M.J.; Deane, A.M. Observed appetite and nutrient intake three months after ICU discharge. Clin. Nutr. 2019, 38, 1215-1220. [CrossRef]

35. Merriweather, J.L.; Griffith, D.M.; Walsh, T.S. Appetite during the recovery phase of critical illness: A cohort study. Eur. J. Clin. Nutr. 2018, 72, 986-992. [CrossRef]

36. Nematy, M.; O’Flynn, J.E.; Wandrag, L.; Brynes, A.E.; Brett, S.J.; Patterson, M.; Ghatei, M.A.; Bloom, S.R.; Frost, G.S. Changes in appetite related gut hormones in intensive care unit patients: A pilot cohort study. Crit. Care 2006, 10, R10. [CrossRef]

37. Vesnaver, E.; Keller, H.H. Social influences and eating behavior in later life: A review. J. Nutr. Gerontol. Geriatr. 2011, 30, 2-23. [CrossRef]

38. Wansink, B. Environmental factors that increase the food intake and consumption volume of unknowing consumers. Annu. Rev. Nutr. 2004, 24, 455-479. [CrossRef]

39. Keller, H.; Allard, J.; Vesnaver, E.; Laporte, M.; Gramlich, L.; Bernier, P.; Davidson, B.; Duerksen, D.; Jeejeebhoy, K.; Payette, H. Barriers to food intake in acute care hospitals: A report of the Canadian Malnutrition Task Force. J. Hum. Nutr. Diet. 2015, 28, 546-557. [CrossRef]

40. Naithani, S.; Whelan, K.; Thomas, J.; Gulliford, M.C.; Morgan, M. Hospital inpatients' experiences of access to food: A qualitative interview and observational study. Health Expect 2008, 11, 294-303. [CrossRef]

41. Preiser, J.C.; Ichai, C.; Orban, J.C.; Groeneveld, A.B. Metabolic response to the stress of critical illness. Br. J. Anaesth. 2014, 113, 945-954. [CrossRef] [PubMed]

42. Preiser, J.C. High protein intake during the early phase of critical illness: Yes or no? Crit. Care 2018, 22, 261. [CrossRef] [PubMed]

43. Van Zanten, A.R.H.; De Waele, E.; Wischmeyer, P.E. Nutrition therapy and critical illness: Practical guidance for the ICU, post-ICU, and long-term convalescence phases. Crit. Care 2019, 23, 368. [CrossRef] [PubMed]

44. Tatucu-Babet, O.A.; Fetterplace, K.; Lambell, K.; Miller, E.; Deane, A.M.; Ridley, E.J. Is Energy Delivery Guided by Indirect Calorimetry Associated With Improved Clinical Outcomes in Critically Ill Patients? A Systematic Review and Meta-analysis. Nutr. Metab. Insights 2020, 13. [CrossRef]

45. Oshima, T.; Berger, M.M.; De Waele, E.; Guttormsen, A.B.; Heidegger, C.P.; Hiesmayr, M.; Singer, P.; Wernerman, J.; Pichard, C. Indirect calorimetry in nutritional therapy. A position paper by the ICALIC study group. Clin. Nutr. 2017, 36, 651-662. [CrossRef]

46. Delsoglio, M.; Dupertuis, Y.M.; Oshima, T.; van der Plas, M.; Pichard, C. Evaluation of the accuracy and precision of a new generation indirect calorimeter in canopy dilution mode. Clin. Nutr. 2019, 39, 1927-1934. [CrossRef]

47. Oshima, T.; Delsoglio, M.; Dupertuis, Y.M.; Singer, P.; De Waele, E.; Veraar, C.; Heidegger, C.P.; Wernermann, J.; Wischmeyer, P.E.; Berger, M.M.; et al. The clinical evaluation of the new indirect calorimeter developed by the ICALIC project. Clin. Nutr. 2020, 39, 3105-3111. [CrossRef]

48. Tatucu-Babet, O.A.; Ridley, E.J.; Tierney, A.C. Prevalence of Underprescription or Overprescription of Energy Needs in Critically Ill Mechanically Ventilated Adults as Determined by Indirect Calorimetry: A Systematic Literature Review. JPEN J. Parenter. Enter. Nutr. 2016, 40, 212-225. [CrossRef] 
49. Fraipont, V.; Preiser, J.C. Energy estimation and measurement in critically ill patients. JPEN J. Parenter. Enter. Nutr. 2013, 37, 705-713. [CrossRef]

50. Berger, M.M. How to prescribe nutritional support using computers. World Rev. Nutr. Diet. 2013, 105, 32-42. [CrossRef]

51. Preiser, J.C.; Laureys, S.; van Zanten, A.R.H.; Van Gossum, A. Computer-Assisted Prescription: The Future of Nutrition Care? JPEN J. Parenter. Enter. Nutr. 2020. [CrossRef] [PubMed]

52. Berger, M.M.; Revelly, J.P.; Wasserfallen, J.B.; Schmid, A.; Bouvry, S.; Cayeux, M.C.; Musset, M.; Maravic, P.; Chiolero, R.L. Impact of a computerized information system on quality of nutritional support in the ICU. Nutrition 2006, 22, 221-229. [CrossRef] [PubMed]

53. Vasiloglou, M.F.; Christodoulidis, S.; Reber, E.; Stathopoulou, T.; Lu, Y.; Stanga, Z.; Mougiakakou, S. What Healthcare Professionals Think of “Nutrition \& Diet” Apps: An International Survey. Nutrients 2020, 12, 2214. [CrossRef]

54. Evans, D.C.; Corkins, M.R.; Malone, A.; Miller, S.; Mogensen, K.M.; Guenter, P.; Jensen, G.L.; Committee, A.M. The Use of Visceral Proteins as Nutrition Markers: An ASPEN Position Paper. Nutr. Clin. Pract. 2020. [CrossRef]

55. Bear, D.E.; Griffith, D.; Puthucheary, Z.A. Emerging outcome measures for nutrition trials in the critically ill. Curr. Opin. Clin. Nutr. Metab. Care 2018, 21, 417-422. [CrossRef]

56. Ridley, E.J.; Chapple, L.S.; Chapman, M.J. Nutrition intake in the post-ICU hospitalization period. Curr. Opin. Clin. Nutr. Metab. Care 2020, 23, 111-115. [CrossRef]

57. Higgins, T.L.; Murray, M.; Kett, D.H.; Fulda, G.; Kramer, K.M.; Gelmont, D.; Dedhia, H.V.; Levy, H.; Teres, D.; Zaloga, G.P.; et al. Trace element homeostasis during continuous sedation with propofol containing EDTA versus other sedatives in critically ill patients. Intensive Care Med. 2000, 26 (Suppl. 4), S413-S421. [CrossRef]

58. Kamel, A.Y.; Dave, N.J.; Zhao, V.M.; Griffith, D.P.; Connor, M.J., Jr.; Ziegler, T.R. Micronutrient Alterations During Continuous Renal Replacement Therapy in Critically Ill Adults: A Retrospective Study. Nutr. Clin. Pract. 2018, 33, 439-446. [CrossRef]

59. Vankrunkelsven, W.; Gunst, J.; Amrein, K.; Bear, D.E.; Berger, M.M.; Christopher, K.B.; Fuhrmann, V.; Hiesmayr, M.; Ichai, C.; Jakob, S.M.; et al. Monitoring and parenteral administration of micronutrients, phosphate and magnesium in critically ill patients: The VITA-TRACE survey. Clin. Nutr. 2020. [CrossRef]

60. Duncan, A.; Talwar, D.; McMillan, D.C.; Stefanowicz, F.; O'Reilly, D.S. Quantitative data on the magnitude of the systemic inflammatory response and its effect on micronutrient status based on plasma measurements. Am. J. Clin. Nutr. 2012, 95, 64-71. [CrossRef]

61. Galloway, P.; McMillan, D.C.; Sattar, N. Effect of the inflammatory response on trace element and vitamin status. Ann. Clin. Biochem. 2000, 37, 289-297. [CrossRef]

62. Manson, J.E.; Bassuk, S.S. Vitamin and Mineral Supplements: What Clinicians Need to Know. JAMA 2018, 319, 859-860. [CrossRef]

63. Rousseau, A.F.; Losser, M.R.; Ichai, C.; Berger, M.M. ESPEN endorsed recommendations: Nutritional therapy in major burns. Clin. Nutr. 2013, 32, 497-502. [CrossRef] [PubMed]

64. Casaer, M.P.; Bellomo, R. Micronutrient deficiency in critical illness: An invisible foe? Intensive Care Med. 2019, 45, 1136-1139. [CrossRef] [PubMed]

65. Blass, S.C.; Goost, H.; Burger, C.; Tolba, R.H.; Stoffel-Wagner, B.; Stehle, P.; Ellinger, S. Extracellular micronutrient levels and pro-/antioxidant status in trauma patients with wound healing disorders: Results of a cross-sectional study. Nutr. J. 2013, 12, 157. [CrossRef] [PubMed]

66. Ostermann, M.; Summers, J.; Lei, K.; Card, D.; Harrington, D.J.; Sherwood, R.; Turner, C.; Dalton, N.; Peacock, J.; Bear, D.E. Micronutrients in critically ill patients with severe acute kidney injury-A prospective study. Sci. Rep. 2020, 10, 1505. [CrossRef] [PubMed]

67. Rech, M.; To, L.; Tovbin, A.; Smoot, T.; Mlynarek, M. Heavy metal in the intensive care unit: A review of current literature on trace element supplementation in critically ill patients. Nutr. Clin. Pract. 2014, 29, 78-89. [CrossRef] [PubMed]

68. Osland, E.; Powlesland, H.; Guthrie, T.; Lewis, C.A.; Memon, M.A. Micronutrient management following bariatric surgery: The role of the dietitian in the postoperative period. Ann. Transl. Med. 2020, 8, S9. [CrossRef]

69. Berger, M.M.; Pantet, O.; Schneider, A.; Ben-Hamouda, N. Micronutrient Deficiencies in Medical and Surgical Inpatients. J. Clin. Med. 2019, 8, 931. [CrossRef] 
70. Lasocki, S.; Lefebvre, T.; Mayeur, C.; Puy, H.; Mebazaa, A.; Gayat, E.; Frog-Icu Study Group. Iron deficiency diagnosed using hepcidin on critical care discharge is an independent risk factor for death and poor quality of life at one year: An observational prospective study on 1161 patients. Crit. Care 2018, 22, 314. [CrossRef]

71. Haas, J.D.; Brownlie, T.T. Iron deficiency and reduced work capacity: A critical review of the research to determine a causal relationship. J. Nutr. 2001, 131, 676S-690S. [CrossRef]

72. Van Dronkelaar, C.; van Velzen, A.; Abdelrazek, M.; van der Steen, A.; Weijs, P.J.M.; Tieland, M. Minerals and Sarcopenia; The Role of Calcium, Iron, Magnesium, Phosphorus, Potassium, Selenium, Sodium, and Zinc on Muscle Mass, Muscle Strength, and Physical Performance in Older Adults: A Systematic Review. J. Am. Med Dir. Assoc. 2018, 19, 6-11.e13. [CrossRef] [PubMed]

73. Nair, P.; Venkatesh, B.; Center, J.R. Vitamin D deficiency and supplementation in critical illness-the known knowns and known unknowns. Crit. Care 2018, 22, 276. [CrossRef] [PubMed]

74. Amrein, K.; Papinutti, A.; Mathew, E.; Vila, G.; Parekh, D. Vitamin D and critical illness: What endocrinology can learn from intensive care and vice versa. Endocr. Connect. 2018, 7, R304-R315. [CrossRef] [PubMed]

75. Girgis, C.M. Vitamin D and Skeletal Muscle: Emerging Roles in Development, Anabolism and Repair. Calcif. Tissue Int. 2020, 106, 47-57. [CrossRef]

76. Ceglia, L. Vitamin D and skeletal muscle tissue and function. Mol. Asp. Med. 2008, 29, 407-414. [CrossRef]

77. Holick, M.F.; Binkley, N.C.; Bischoff-Ferrari, H.A.; Gordon, C.M.; Hanley, D.A.; Heaney, R.P.; Murad, M.H.; Weaver, C.M. Evaluation, treatment, and prevention of vitamin D deficiency: An Endocrine Society clinical practice guideline. J. Clin. Endocrinol. Metab. 2011, 96, 1911-1930. [CrossRef]

78. Lee, P. How deficient are vitamin D deficient critically ill patients? Crit. Care 2011, 15, 154. [CrossRef]

79. Amrein, K.; Schnedl, C.; Holl, A.; Riedl, R.; Christopher, K.B.; Pachler, C.; Urbanic Purkart, T.; Waltensdorfer, A.; Munch, A.; Warnkross, H.; et al. Effect of high-dose vitamin D3 on hospital length of stay in critically ill patients with vitamin D deficiency: The VITdAL-ICU randomized clinical trial. JAMA 2014, 312, 1520-1530. [CrossRef]

80. Stockton, K.A.; Mengersen, K.; Paratz, J.D.; Kandiah, D.; Bennell, K.L. Effect of vitamin D supplementation on muscle strength: A systematic review and meta-analysis. Osteoporos. Int. 2011, 22, 859-871. [CrossRef]

81. Ebid, A.A.; El-Shamy, S.M.; Amer, M.A. Effect of vitamin D supplementation and isokinetic training on muscle strength, explosive strength, lean body mass and gait in severely burned children: A randomized controlled trial. Burns 2017, 43, 357-365. [CrossRef] [PubMed]

82. Rousseau, A.F.; Foidart-Desalle, M.; Ledoux, D.; Remy, C.; Croisier, J.L.; Damas, P.; Cavalier, E. Effects of cholecalciferol supplementation and optimized calcium intakes on vitamin D status, muscle strength and bone health: A one-year pilot randomized controlled trial in adults with severe burns. Burns 2015, 41, 317-325. [CrossRef] [PubMed]

83. Reuter, S.E.; Evans, A.M. Carnitine and acylcarnitines: Pharmacokinetic, pharmacological and clinical aspects. Clin. Pharmacokinet. 2012, 51, 553-572. [CrossRef] [PubMed]

84. Bonafe, L.; Berger, M.M.; Que, Y.A.; Mechanick, J.I. Carnitine deficiency in chronic critical illness. Curr. Opin. Clin. Nutr. Metab. Care 2014, 17, 200-209. [CrossRef] [PubMed]

85. Hill, N.E.; Murphy, K.G.; Singer, M. Ghrelin, appetite and critical illness. Curr. Opin. Crit. Care 2012, 18, 199-205. [CrossRef]

86. Heyland, D.K.; van Zanten, A.R.H.; Grau-Carmona, T.; Evans, D.; Beishuizen, A.; Schouten, J.; Hoiting, O.; Bordeje, M.L.; Krell, K.; Klein, D.J.; et al. A multicenter, randomized, double-blind study of ulimorelin and metoclopramide in the treatment of critically ill patients with enteral feeding intolerance: PROMOTE trial. Intensive Care Med. 2019, 45, 647-656. [CrossRef]

87. Wischmeyer, P.E.; Suman, O.E.; Kozar, R.; Wolf, S.E.; Molinger, J.; Pastva, A.M. Role of anabolic testosterone agents and structured exercise to promote recovery in ICU survivors. Curr. Opin. Crit. Care 2020, 26, 508-515. [CrossRef]

88. Parry, S.M.; Chapple, L.S.; Mourtzakis, M. Exploring the Potential Effectiveness of Combining Optimal Nutrition With Electrical Stimulation to Maintain Muscle Health in Critical Illness: A Narrative Review. Nutr. Clin. Pract. 2018, 33, 772-789. [CrossRef]

89. Heyland, D.K.; Stapleton, R.D.; Mourtzakis, M.; Hough, C.L.; Morris, P.; Deutz, N.E.; Colantuoni, E.; Day, A.; Prado, C.M.; Needham, D.M. Combining nutrition and exercise to optimize survival and recovery from critical illness: Conceptual and methodological issues. Clin. Nutr. 2016, 35, 1196-1206. [CrossRef] 
90. Nakamura, K.; Nakano, H.; Naraba, H.; Mochizuki, M.; Takahashi, Y.; Sonoo, T.; Hashimoto, H.; Morimura, N. High protein versus medium protein delivery under equal total energy delivery in critical care: A randomized controlled trial. Clin. Nutr. 2020. [CrossRef]

91. Morton, R.W.; Traylor, D.A.; Weijs, P.J.M.; Phillips, S.M. Defining anabolic resistance: Implications for delivery of clinical care nutrition. Curr. Opin. Crit. Care 2018, 24, 124-130. [CrossRef] [PubMed]

92. Mechanick, J.I.; Brett, E.M. Endocrine and metabolic issues in the management of the chronically critically ill patient. Crit. Care Clin. 2002, 18, 619-641. [CrossRef]

93. Wehbeh, L.; Dobs, A.S. Opioids and the Hypothalamic-Pituitary-Gonadal (HPG) Axis. J. Clin. Endocrinol. Metab. 2020, 105, e3105-e3113. [CrossRef] [PubMed]

94. Li, H.; Guo, Y.; Yang, Z.; Roy, M.; Guo, Q. The efficacy and safety of oxandrolone treatment for patients with severe burns: A systematic review and meta-analysis. Burns 2016, 42, 717-727. [CrossRef] [PubMed]

95. Takala, J.; Ruokonen, E.; Webster, N.R.; Nielsen, M.S.; Zandstra, D.F.; Vundelinckx, G.; Hinds, C.J. Increased mortality associated with growth hormone treatment in critically ill adults. N. Engl. J. Med. 1999, 341, 785-792. [CrossRef] [PubMed]

96. Demling, R.H. Comparison of the anabolic effects and complications of human growth hormone and the testosterone analog, oxandrolone, after severe burn injury. Burns 1999, 25, 215-221. [CrossRef]

97. Herndon, D.N.; Hart, D.W.; Wolf, S.E.; Chinkes, D.L.; Wolfe, R.R. Reversal of catabolism by beta-blockade after severe burns. N. Engl. J. Med. 2001, 345, 1223-1229. [CrossRef]

98. Porro, L.J.; Al-Mousawi, A.M.; Williams, F.; Herndon, D.N.; Mlcak, R.P.; Suman, O.E. Effects of propranolol and exercise training in children with severe burns. J. Pediatr. 2013, 162, 799-803.e791. [CrossRef]

99. Chiolero, R.L.; Breitenstein, E.; Thorin, D.; Christin, L.; de Tribolet, N.; Freeman, J.; Jequier, E.; Schutz, Y. Effects of propranolol on resting metabolic rate after severe head injury. Crit. Care Med. 1989, 17, 328-334. [CrossRef]

100. Ham, D.J.; Caldow, M.K.; Lynch, G.S.; Koopman, R. Leucine as a treatment for muscle wasting: A critical review. Clin. Nutr. 2014, 33, 937-945. [CrossRef]

101. Bear, D.E.; Langan, A.; Dimidi, E.; Wandrag, L.; Harridge, S.D.R.; Hart, N.; Connolly, B.; Whelan, K. beta-Hydroxy-beta-methylbutyrate and its impact on skeletal muscle mass and physical function in clinical practice: A systematic review and meta-analysis. Am. J. Clin. Nutr. 2019, 109, 1119-1132. [CrossRef] [PubMed]

Publisher's Note: MDPI stays neutral with regard to jurisdictional claims in published maps and institutional affiliations.

(C) 2020 by the authors. Licensee MDPI, Basel, Switzerland. This article is an open access article distributed under the terms and conditions of the Creative Commons Attribution (CC BY) license (http://creativecommons.org/licenses/by/4.0/). 